\title{
COMPARISON OF THE EFFECTIVENESS OF BASTA, BIALAPHOS AND GLUFOSINATE AMMONIUM FOR SELECTING TRANSFORMED OIL PALM TISSUES
}

\section{A RAHMAN NURFAHISZA*; MD AMAN RAFIQAH*; GHULAM KADIR AHMAD PARVEEZ* and OMAR ABDUL RASID*}

\begin{abstract}
One of the important requirements for producing transgenic plants is the ability to isolate true transformed cells and regenerate into complete plants without chimera and escapes. Therefore, an efficient selection process is essential. In this study, three different selection agents, namely Basta, bialaphos and glufosinate ammonium were evaluated on embryogenic calli and embryoids, for their effectiveness on selecting transformed oil palm tissues. Untransformed tissues were used in this study as the minimal concentrations which inhibit the growth of the tissues would be the optimum concentrations for selecting the transformed cells. Based on this study, the growth of embryogenic calli was shown to be fully inhibited at $10 \mathrm{mg}$ litre-1 $^{-1}$ of Basta. Meanwhile, only $3 \mathrm{mg}$ litre ${ }^{-1}$ of bialaphos and glufosinate ammonium are needed to inhibit the embryogenic calli. For oil palm embryoid cultures, the minimal concentration for Basta was determined at $20 \mathrm{mg} \mathrm{litre}^{-1}$ as compared to $5 \mathrm{mg} \mathrm{litre}^{-1}$ for bialaphos and glufosinate ammonium. This result indicated that a higher concentration of Basta is needed to completely inhibit the growth of oil palm tissues as compared to bialaphos and glufosinate ammonium. Furthermore, these observations revealed that embryogenic calli are more sensitive to the three selection agents as compared to embryoids. The information gained from this study will be used as a guideline to increase the efficiency for selecting transformed oil palm cells and producing transgenic oil palm.
\end{abstract}

Keywords: Basta, bialaphos, glufosinate ammonium, minimal inhibitory concentration, oil palm.

Date received: 27 April 2016; Sent for revision: 26 May 2016; Received in final form: 5 August 2016; Accepted: 6 August 2016.

\section{INTRODUCTION}

Genetic transformation has been identified as a tool for synthesising high-value-added products in transgenic oil palm (Parveez et al., 2015a). There are numerous reports on successful genetic transformation of other crops such as maize (Yan et al., 2010), wheat (Weeks et al., 1993) and rice (Cao et al., 1992). Particle bombardment is one of the common transformation methods used to transfer

Malaysian Palm Oil Board, 6 Persiaran Institusi, Bandar Baru Bangi, 43000 Kajang, Selangor, Malaysia.

E-mail: parveez@mpob.gov.my foreign genes of interest into plant cells. However, besides the transfer of gene of interest, a selectable marker gene is always required to be transferred as well as it is essential for selecting and regenerating transformed plant cells. It was previously reviewed that there are approximately 50 selectable marker genes commonly used in transgenic plant research (Miki and McHugh, 2004) which is needed to distinguish the transformed cells which will survive on selection agents. Kanamycin, hygromycin and phosphinothricin (PPT) are among the widely used selection agents in plant transformation work. The use of these selection agents depends on the efficiency, availability and applicability across a wide range of plant species and the regenerative 
efficacy in plant tissue culture systems (Sundar and Sakthivel, 2008).

Bar gene is known as an effective selectable marker for monocots crops such as wheat, corn and also oil palm. Bar gene, which was isolated from Streptomyces hygroscopius, encodes phosphinothricin $\mathrm{N}$-acetyltransferase (PAT) enzyme. This enzyme will detoxify herbicide PPT by acetylation using acetylcoenzyme A as cofactor (De Block et al., 1987). The PPT is an analogue of glutamate which will become a competitive inhibitor of the enzyme glutamine synthetase. The enzyme glutamine synthetase plays a role in removing toxic ammonia from cell by catalysing the conversion of glutamate to glutamine. The inhibition of glutamine synthetase will cause the accumulation of ammonia and ultimately the plant cell death (Tachibana et al., 1986).

The selectable marker, bar gene confers resistance to phosphinothricin, Basta, bialaphos and glufosinate ammonium. Basta has been widely used as the selection agent for monocot transformation studies such as wheat (Mariana et al., 2002), sugarcane (Ijaz et al., 2012) and rice (Christou et al., 1991). The use of bialaphos as a selection agent has been reported in soyabean (Kita et al., 2009) and barley (Koprek et al., 1996). Meanwhile, glufosinate has also been used as a selection agent in a number of plant transformation works such as tomato (Fani et al., 2012) and sweet potato (Shin et al., 2011).

In the first report on successful oil palm transformation using biolistic device (Parveez et al., 2000), bar gene and Basta were used for selection of transformants. Later, other selectable markers, green fluorescence protein (Majid and Parveez, 2007; Parveez and Majid, 2008; Masanietal., 2014), mannose (Bahariah et al., 2012; 2013) and 2-deoxyglucose (Izawati et al., 2012; 2015) were evaluated for oil palm. Basta was the most effective selection agent and widely used in oil palm transformation. It was observed that the transformed cells carrying bar gene survived on herbicide Basta containing media while the untransformed cells eventually died. However, for oil palm, recently there is a first report indicating the presence of escapes in some of the plantlets obtained after selection on herbicide Basta, which might be due to non-optimal selection process (Nurfahisza et al., 2014). The non-optimal concentration of selection agents used may have caused the regeneration of escape plants. On the other hand, selection on a higher concentration of Basta may have inhibited the transformed cells. In order to tighten the selection process, a study should be carried out at different tissue culture stages to determine the minimal inhibitory concentration of a particular selection agent needed for different types of oil palm tissues.

Besides herbicide Basta, bar gene also confers resistance to other selection agents such as bialaphos and glufosinate ammonium. Herbicide Basta is a commercial formulation of glufosinate, which is the ammonium salt of PPT (Fromm et al., 1990). Meanwhile, bialaphos is a tripeptide herbicide produced by Streptomyces hygroscopius consisting of two L-alanine molecules and one L-glutamic acid analog called PPT (Ogawa et al., 1973; Kondo et al., 2002). To date, no study evaluating the use of bialaphos and glufosinate ammonium as selection agent for oil palm has been reported. This article reports the evaluation of bialaphos, glufosinate ammonium and Basta as selection agents for oil palm. Work was carried out on oil palm tissues at two different stages of regeneration, namely embryogenic calli and embryoids. As different tissues have different sensitiveness towards a given selection agent (Zang et al., 2009), this information is extremely crucial in order to ensure a tight selection at different stages of tissue development during the selection and regeneration of transformed cells.

\section{MATERIALS AND METHODS}

\section{Plant Materials}

Oil palm cabbages were subcultured onto solid callus initiation media [MS salts (Murashige and Skoog, 1962) $+\mathrm{Y}_{3}$ vitamins (Eeuwans, 1976) + $0.1 \mathrm{~g}$ litre $^{-1}$ myo-inositol and L-glutamine $+3 \%$ sucrose $+5 \times 10^{-5} \mathrm{M}$ 2,4-dichlorophenoxyacetic acid (2, 4 -D) $+0.25 \%$ activated charcoal $+0.7 \%$ agar] and incubated in the dark at $28^{\circ} \mathrm{C}$. The calli formed were subcultured every four weeks onto same media. Since experiments need embryogenic calli and embryoids as a target tissue, subculturing on callus initiation media was carried out until embryogenic calli were formed. Meanwhile, the embryoids were obtained by subculturing the embryogenic calli for every four weeks onto solid embryogenic calli (EC) media containing MS (Murashige and Skoog, 1962), macro and micronutrients supplemented with $1 \mathrm{mg}$ litre $^{-1}$ naphthalene acetic acid (NAA) and $30 \mathrm{~g} \mathrm{litre}^{-1}$ sucrose with $\mathrm{pH}$ 5.7.

\section{Sensitivity to Selection Agent}

In order to determine the minimal inhibitory concentration of the three different selection agents (Basta, bialaphos and glufosinate ammonium), various concentrations were added in EC media. For Basta, the concentrations tested were 0, 5, 10, 15, 20, 25, 30, 35, 40, 45 and $50 \mathrm{mg}$ litre $^{-1}$. For bialaphos and glufosinate, concentrations used were $0,1,2,3,4,5,6,7,8,9$ and $10 \mathrm{mg}$ litre $^{-1}$. For each concentration, five replicates (plates) were prepared to make it statistically sound. In each plate, $0.5 \mathrm{~g}$ of embryogenic calli and $1.0 \mathrm{~g}$ of embryoids were cultured/transferred on fresh EC media and incubated at $28^{\circ} \mathrm{C}$ in light/dark condition at $16 \mathrm{hr} /$ 
$8 \mathrm{hr}$. Subculturing onto fresh media containing selection agents was carried out every four weeks and the weight of the calli was recorded monthly for six months. The characteristics of the samples was also observed and recorded during the subculture.

\section{Determination of Efficient Selection}

The minimal inhibitory concentration was determined based on the proliferation percentage of treated tissue against control tissue during sixmonth culture period. In this experiment, the tissue on media without selection agent (untreated) acted as control tissue where the proliferation rate was considered as $100 \%$. The weight of the treated tissue and control (untreated) was recorded every month and the means of five replicates were used in final calculations. Proliferation percentages were calculated by using the formula given below:

$$
\begin{aligned}
& \text { Proliferation } \\
& \text { percentage }(\%)
\end{aligned}=\frac{\begin{array}{l}
\text { (Final weight }- \text { initial weight }) \\
\text { treated samples }
\end{array}}{\begin{array}{l}
\text { (Final weight }- \text { initial weight }) \\
\text { control samples }
\end{array}} \times 100
$$

The final weight is the sample weight during subculturing on that month while initial weight is the sample weight when starting the experiment. In this formula, the control was considered to have $100 \%$ proliferation (Dennehey et al., 1994) assuming that there were no inhibitions or stresses which will reduce the proliferation rate (Parveez et al., 1996). The proliferation percentages for each concentration of selection agents were plotted for six months culture period.

\section{RESULTS AND DISCUSSION}

\section{The Effectiveness of Three Selection Agents}

The minimal inhibitory concentration of the selection agents is defined as a concentration which effectively inhibits the growth of untransfomed calli. As bar gene is the main selectable marker used in oil palm transformation, experiments were carried out to determine the minimal inhibitory concentrations for three different selection agents, namely Basta, bialaphos and glufosinate ammonium. This study focussed on two different stages of oil palm tissue culture, namely embryogenic calli and embryoids. Based on the graph of proliferation percentage against culture duration (month) (Figure 1a), 10 $\mathrm{mg}$ litre $^{-1}$ of Basta was shown to be the minimal concentration that could sufficiently inhibit the growth of untransformed embryogenic calli. On the other hand, a higher concentration of Basta, $20 \mathrm{mg}$ litre $^{-1}$, was needed to effectively suppress the growth of untransformed embryoids. Same concentration of glufosinate ammonium and bialaphos were effectively inhibit the growth of oil palm embryogenic calli and embryoids. It was observed that for both glufosinate ammonium (Figure 1b) and bialaphos (Figure 1c), a concentration of $3 \mathrm{mg} \mathrm{litre}^{-1}$ was required to inhibit the growth of embryogenic calli. For the embryoids, a slightly higher concentration, $5 \mathrm{mg}$ litre $^{-1}$, was required to inhibit the growth of the untransformed embryoids.

From this study, the results also showed a higher concentration of Basta was needed to inhibit the growth of either embryogenic calli or embryoids. Basta (Bayer Cropscience, Germany), a commercial formulation of glufosinate (Fromm et al., 1990) containing $150 \mathrm{~g}_{\text {litre }} \mathrm{e}^{-1}$ of glufosinate ammonium was diluted and used in this study. The results showed that a higher concentration of Basta was needed as compared to bialaphos and glufosinate ammonium. Study on maize (Dennehey et al., 1994) also showed that $3 \mathrm{mg}$ litre $^{-1}$ of Basta is needed to select and regenerate the transformants as compared to bialaphos, which requires only 1 mg litre ${ }^{-1}$ for selection. Study on transformation of Gladiolus plants also showed similar result where $6 \mathrm{mg}$ litre $^{-1}$ of Basta was required as compared to 1 $\mathrm{mg} \mathrm{litre}^{-1}$ of bialaphos for isolating transformants (Kamo et al., 1995).

In this study, the oil palm tissue appearance at various concentrations of selection agent was also observed. The tissue on medium containing herbicide Basta (Figure 2) and glufosinate ammonium (Figure 3) turned blackish after six months. The appearance of calli on Basta and glufosinate ammonium showed no difference even though a higher concentration of Basta was used as compared to glufosinate. This showed that the Basta is less effective than glufosinate ammonium and needs a higher concentration to inhibit the untransformed callus growth. Meanwhile, calli on medium containing bialaphos (Figure 4) showed a different effect on tissue appearance where calli turned brownish after six months. Bialaphos and glufosinate ammonium showed the same minimal concentration to inhibit the growth of oil palm tissues but were more blackish on glufosinate ammonium as compared to bialaphos. The difference might be due to the difference in the chemical structure between these two agents. The tripeptide form of PPT (bialaphos) may be more efficiently utilised by plant cells than unconjugated PPT (Basta and glufosinate) (Kamo and Van Eck, 1997). Thus, the different effect towards oil palm tissues might be because of the difference in the chemical structure.

The minimal concentrations of a selection agent should be determined precisely to make sure that the concentration used is sufficiently high to cause lethality to untransformed cells but would allow transformed cells to proliferate. A low concentration of selection agents may cause the 'escapes' to 
a) Basta

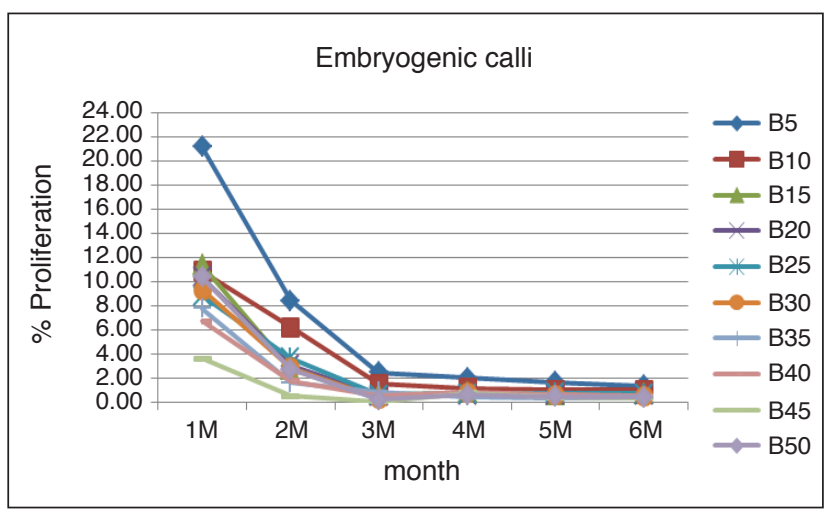

b) Glufosinate ammonium
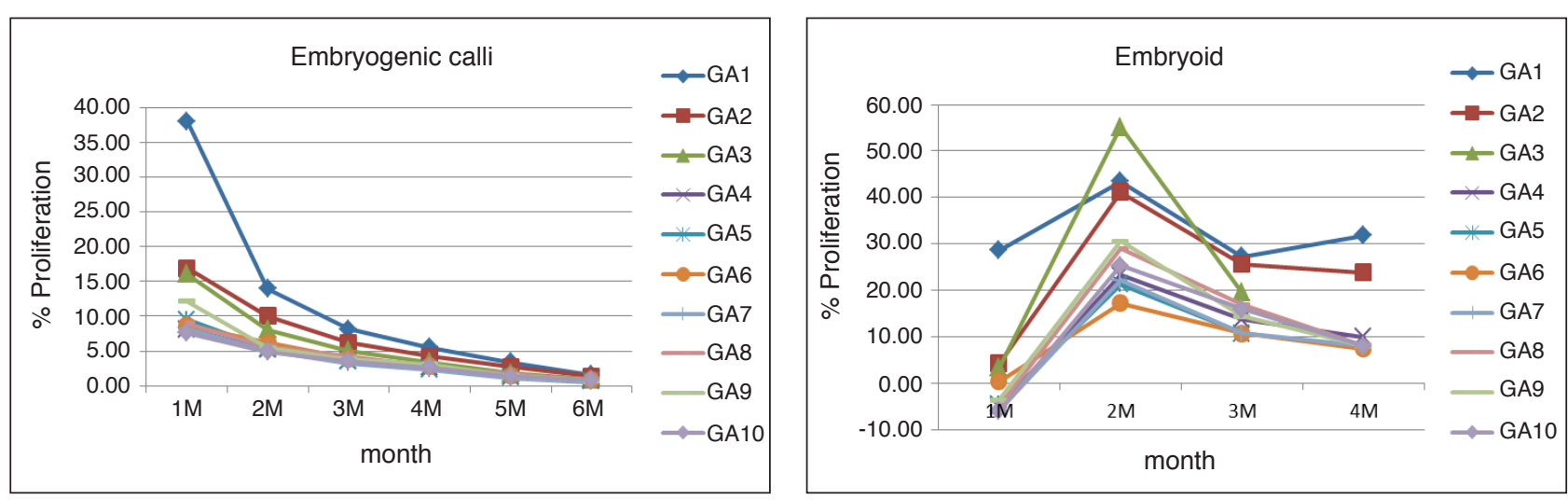

c) Bialaphos
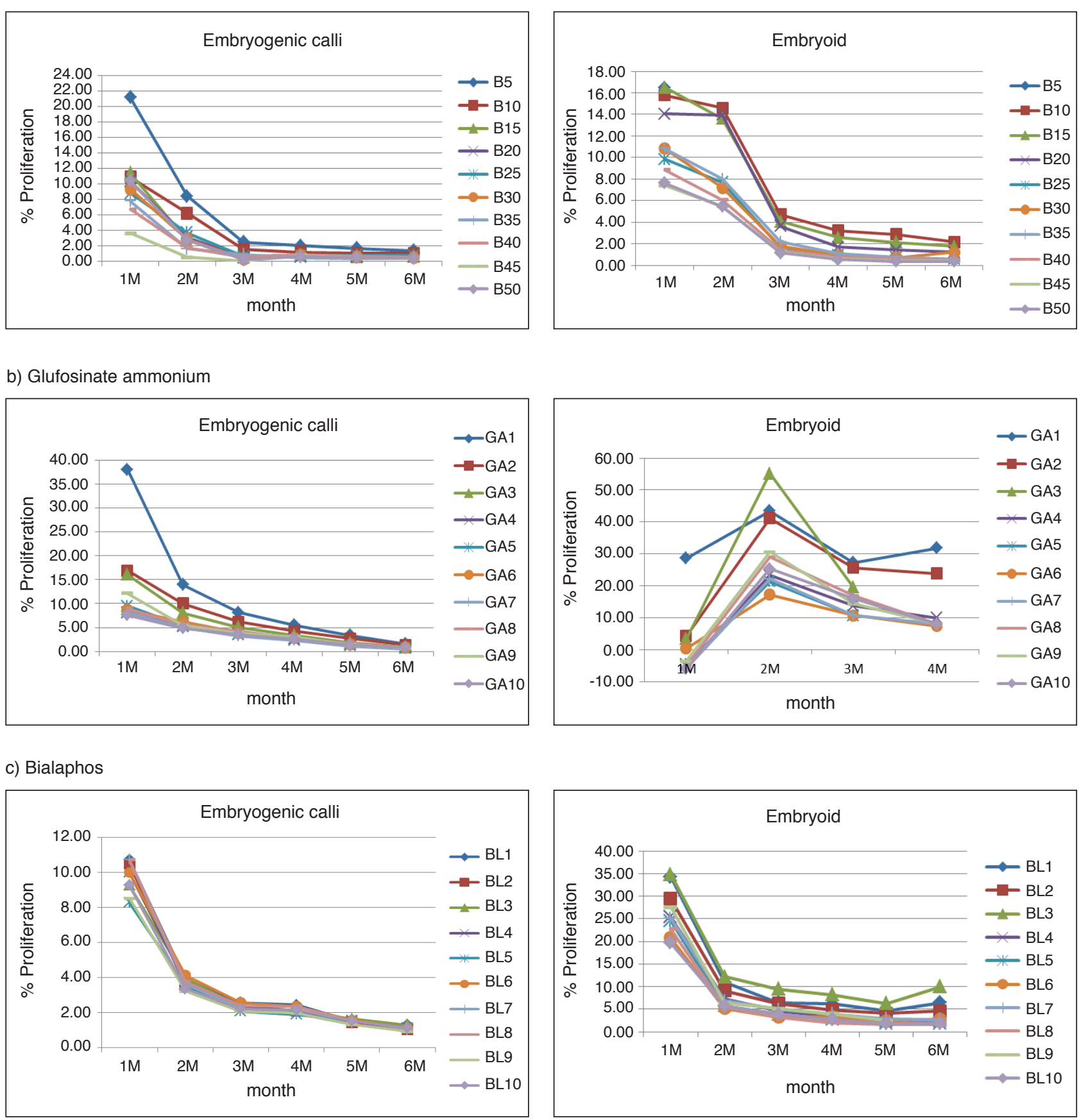

Figure 1. Proliferation percentage of oil palm embryogenic calli and embryoids after six months of culture at different concentrations of a) Basta, b) glufosinate ammonium and c) bialaphos.

develop and will ultimately give rise to many false positives (Ijaz et al., 2012). Escapes will also occur when untransformed cells get protected from the neighbouring transformed cells and survive on selection agents (Bower and Birch, 1992). Analysis on generated oil palm on selection agent Basta also showed the escapes were obtained (Nurfahisza et al., 2014). The problems also occurred on study of citrus where $90 \%$ of generated plantlets were escapes and chimeric (Dominguez et al., 2004). Other than that, study on wheat by Mariana et al. (2002) showed $30 \%$ of escapes were obtained after the selection on
Basta. This problem might be due to non-optimal concentration of selection agents during selection process. Besides that, the escapes may also generate because of the temporal expression of the selectable marker gene (Mariana et al., 2002; Bhore and Shah, 2012). On the other hand, if the concentration is too high, the untransformed as well as transformed cells will lose their ability to survive the selection (Parveez et al., 2007; Ijaz et al., 2012). Moreover, the use of selection agents at high concentrations may also increase the cost (Parveez et al., 1996; Oneto et al., 2010; Ijaz et al., 2012). 


\section{Basta}
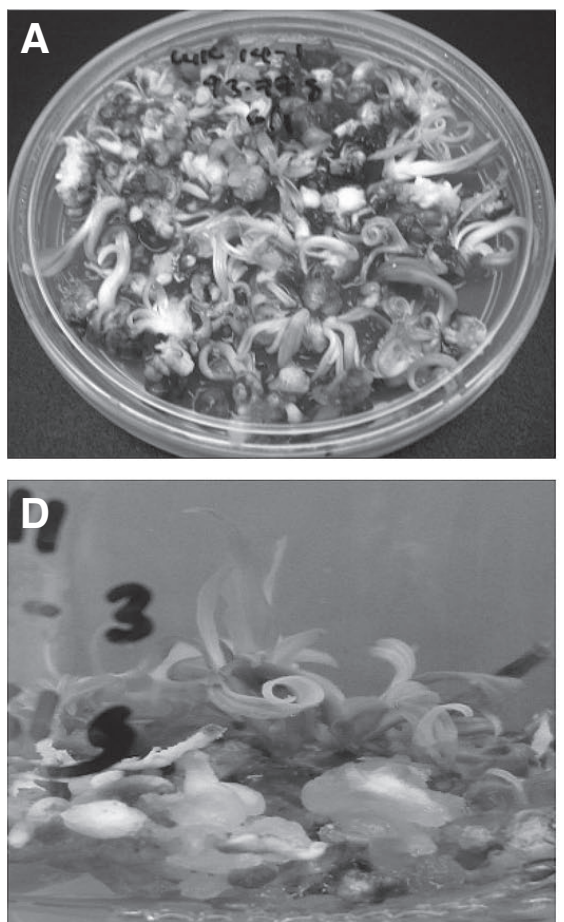
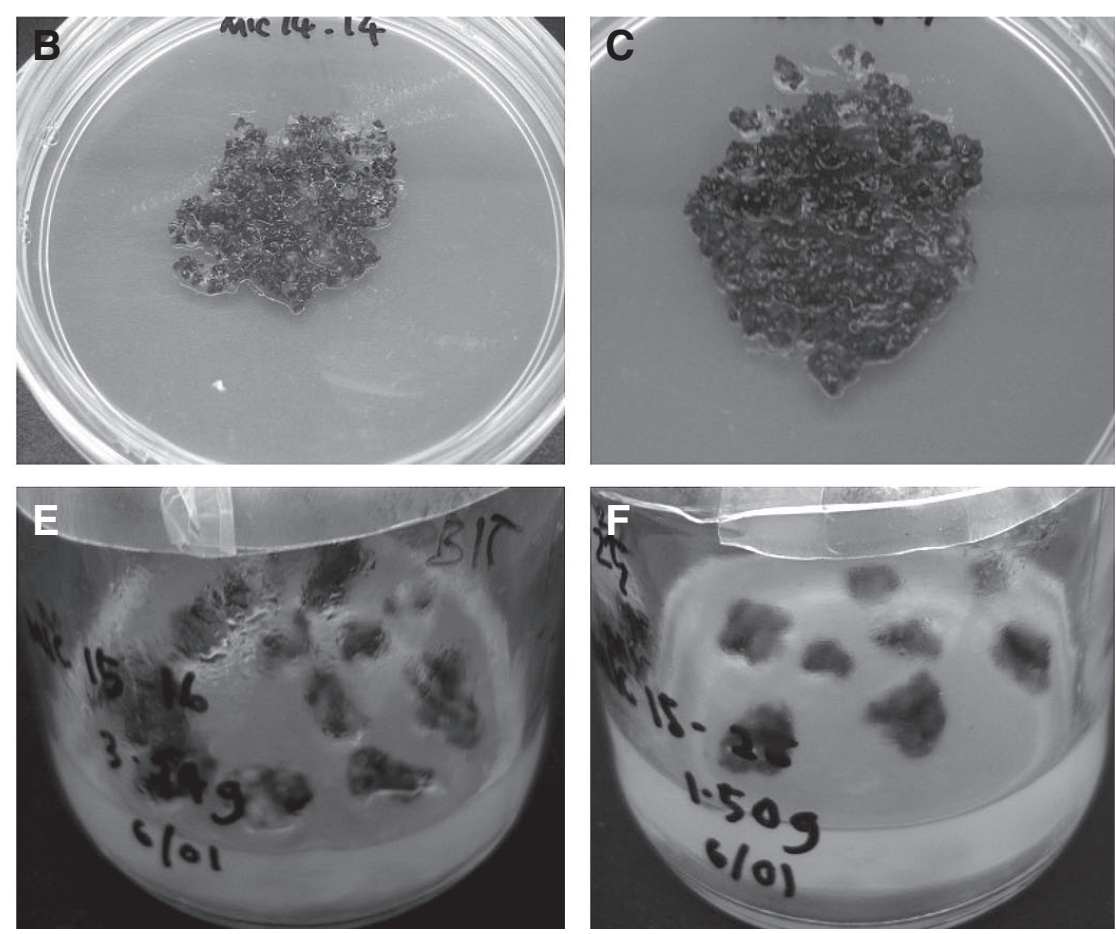

Figure 2. Oil palm embryogenic calli and embryoids after six months of culture on media supplemented with Basta. A) Embryogenic calli on medium without Basta (control). B) Embryogenic calli on medium supplemented with $10 \mathrm{mg}$ litre ${ }^{-1}$ of Basta. C) Embryogenic calli on medium supplemented with $25 \mathrm{mg}$ litre $e^{-1}$ of Basta. D) Embryoids on medium without Basta (control). E) Embryoids on medium supplemented with $15 \mathrm{mg}$ litre-1 of Basta. F) Embryoids on medium supplemented with $20 \mathrm{mg}$ litre-1 of Basta.

\section{Glufosinate ammonium}
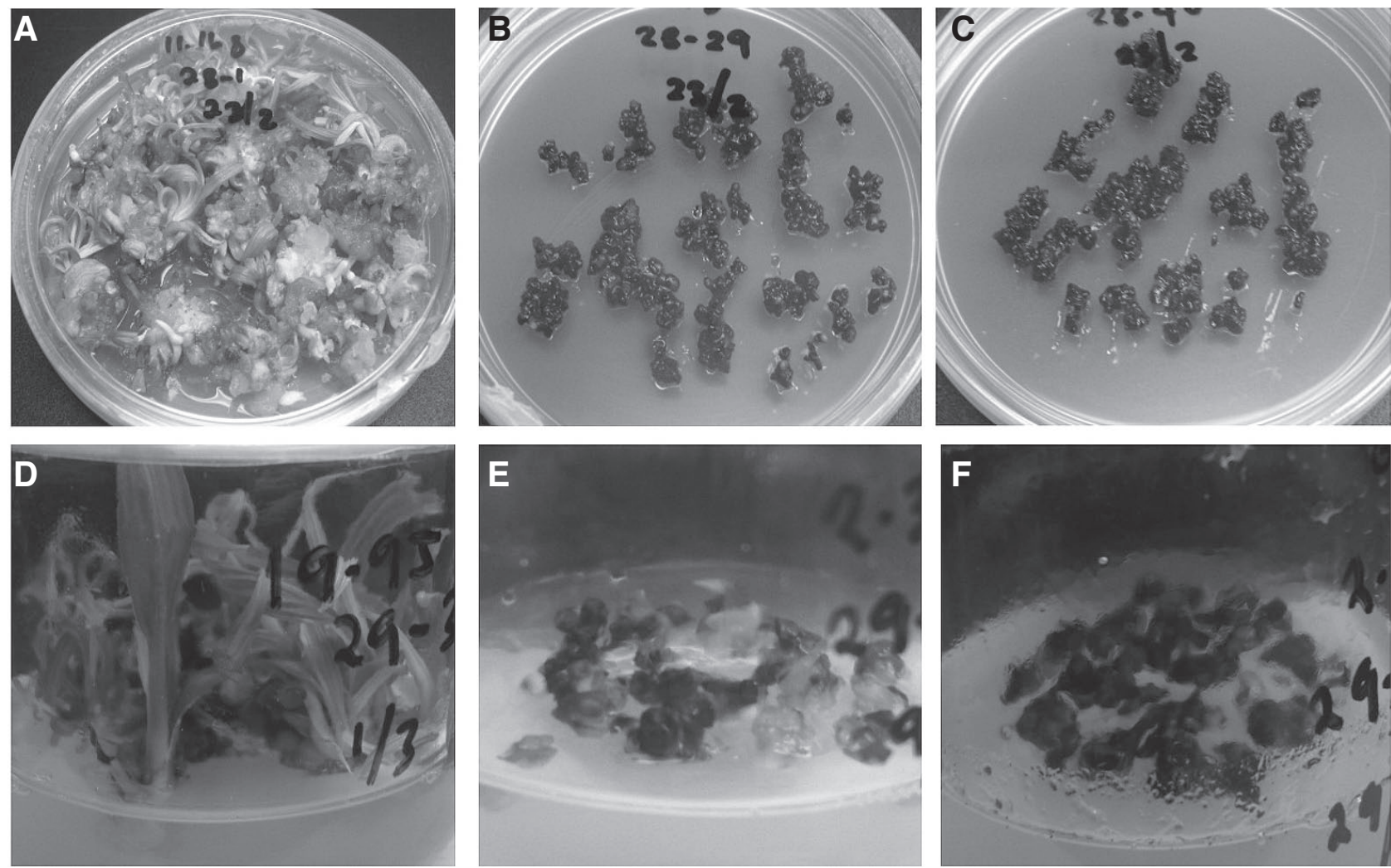

Figure 3. Embryogenic calli and embryoid tissues after six months of culture on media supplemented with glufosinate ammonium. A) Embryogenic calli on media without glufosinate (control). B) Embryogenic calli on media supplemented with $3 \mathrm{mg}$ litre ${ }^{-1}$ of glufosinate. C) Embryogenic calli on media supplemented with $5 \mathrm{mg} \mathrm{litre-1}$ of glufosinate. D) Embryoid tissue on media without glufosinate (control). E) Embryoid tissue on selection media supplemented with $3 \mathrm{mg}$ litre $^{-1}$ of glufosinate. F) Embryoid tissue on media supplemented with $5 \mathrm{mg}$ litre-1 of glufosinate. 


\section{Bialaphos}
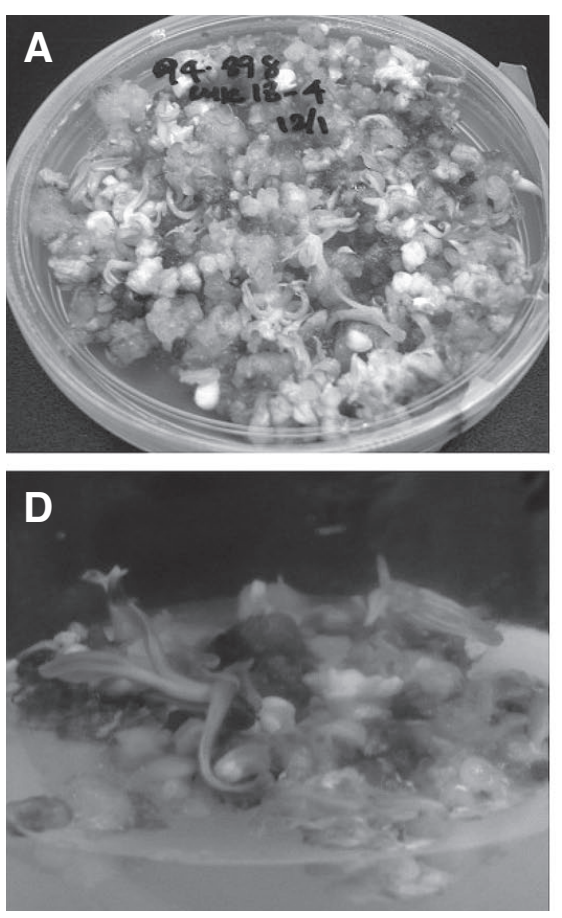
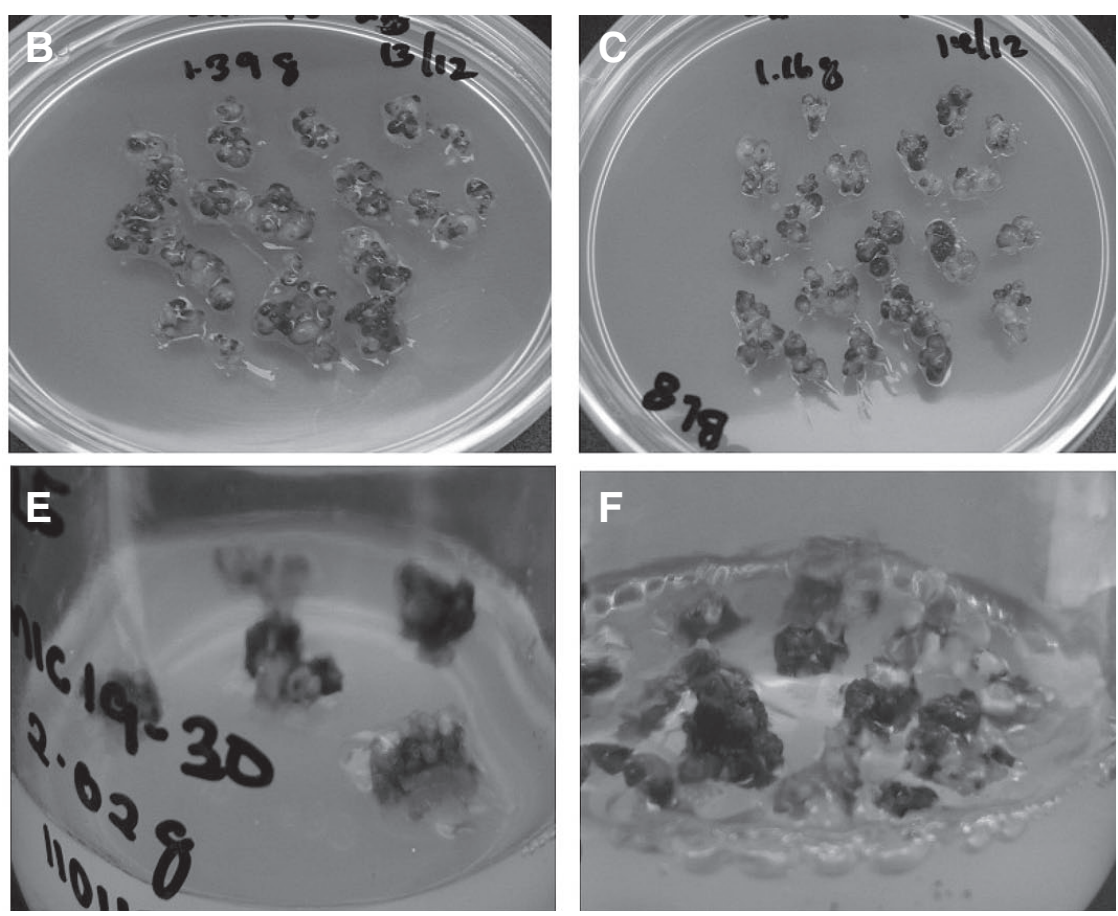

Figure 4. Embryogenic calli and embryoid tissues after six months of culture on media supplemented with bialaphos. A) Embryogenic calli on media without bialaphos (control). B) Embryogenic calli on media supplemented with 3 mg litre-1 of bialaphos. C) Embryogenic calli on media supplemented with $5 \mathrm{mg} \mathrm{litre}^{-1}$ of bialaphos. D) Embryoid tissue on media without bialaphos (control). E) Embryoid tissue on media supplemented with 3 mg litre ${ }^{-1}$ of bialaphos. F) Embryoid tissue on media supplemented with $5 \mathrm{mg} \mathrm{litre}^{-1}$ of bialaphos.

\section{The Sensitivity towards Different Tissues}

The sensitivity of calli at different tissue culture stages was also investigated in this study. The result showed that embryogenic calli were more sensitive to the selection agents compared to embryoids. The different levels of sensitivity to selection agents might be due to several factors such as size, age and morphology of the tissues. Zang et al. (2009) reported that the sweet potato aggregates which were smaller and younger as compared to embryogenic calli were shown to have different sensitivity towards PPT. The concentration at $0.5 \mathrm{mg}$ litre ${ }^{-1}$ of PPT was sufficient to inhibit the growth of sweet potato cell aggregates. In contrast, $5 \mathrm{mg}$ litre ${ }^{-1}$ of PPT was needed to inhibit the growth of sweet potato embryogenic calli (Otani et al., 2003; Choi et al., 2007).

Other than that, recently Parveez et al. (2015b) reported that $50 \mathrm{mg}$ litre $^{-1}$ of Basta was needed to inhibit growth of oil palm embryogenic calli and regenerate transgenic plants. The concentration was higher compared to the concentration obtained from this study. This is because the morphology of material used were different. Calli used for that study were derived from immature embryos. In current study, calli derived from oil palm's cabbage was used. The morphology of calli derived from immature embryos was mostly compact in nature, while the calli derived from cabbage were mostly friable. The differences in their morphology could cause the different level of sensitiveness towards selection agents.

Since the sensitiveness between the tissues towards selection agents is different, it is essential that the minimal inhibitory concentration for a particular selection agent should be determined for each tissue or culture type. This is important to eliminate the chimera and escapes at every stage of oil palm development and improve the selection process in order to increase the efficiency of oil palm transformation.

\section{CONCLUSION}

The results obtained suggest that the three different selection agents tested in this study could be used for oil palm transformation when using bar as a selectable marker gene. Their effectiveness to inhibit the growth of embryogenic calli and embryoids was clearly indicated in this study. The information obtained from this work will be useful in designing an effective selection scheme for oil palm transformation.

\section{ACKNOWLEDGEMENT}

The authors wish to thank the Director-General of MPOB for permission to publish this article. The 
authors also thank the staff of Transgenic Technology and Clonal Propagation Groups of MPOB for their contributions.

\section{REFERENCES}

BAHARIAH, B; PARVEEZ, G K A; MASANI, M Y A; MASURA, S S; KHALID, N and OTHMAN, R Y (2013). Biolistic transformation of oil palm using the phosphomannose isomerase ( $\mathrm{pmi}$ ) gene as a positive selectable marker. Biocatalysis Agricultural Biotechnol, 2: 295-304.

BAHARIAH, B; PARVEEZ, G K A and KHALID N Z (2012). Determination of optimal concentration of mannose as a selection agent for selecting transformed oil palm cells using the phosphomannose isomerase (pmi) gene as the positive selectable marker. J. Oil Palm Res. Vol. 24: 1250-1259.

BHORE, S J and SHAH F S (2012). Genetic transformation of the American oil palm (Elaeis oleifera) immature zygotic embryos with antisense palmitoyl-acyl carrier protein thioesterase (PATE) gene. World Applied Sciences J., 16(3): 362-369.

BOWER, R and BIRCH, R G (1992). Transgenic sugarcane plants obtained by microprojectile bombardment. Plant J., 2: 409-416.

CAO, J; DUAN, X; MCELROY, D and WU, R (1992). Regeneration of herbicide resistant transgenic rice plants following microprojectile-mediated transformation of suspension culture cells. Plant Cell Reports, 11: 586-591.

CHISTOU, P; FORD, T and KOFRON, M (1991). Production of transgenic rice (Oryza sativa L.) plants from agronomically important indica and japonica varieties via electric discharge particle acceleration of exogenous DNA into immature zygotic embryos. Biotechnology, 9: 957-962.

CHOI, H J; CHANDRASEKHAR, T; LEE, H Y and KIM, K M (2007). Production of herbicideresistant transgenic sweetpotato plants through Agrobacterium tumefaciens method. Plant Cell Tissue Organ Culture, 91: 235-242.

DE BLOCK, M; BOTTERMAN, J; VANDERWIELE, M; MONTAGU, M and LEEMANS, J (1987). Engineering herbicide resistance in plants by expression of a detoxifying enzyme. $E M B O$ J., 6 : 2513-2518.

DENNEHEY, B K; PETERSEN, W L; FORDSANTINO, C; PAJEAU, $\mathrm{M}$ and ARMSTRONG,
C L (1994). Comparison of selective agents for use with the selectable marker gene bar in maize transformation. Plant Cell, Tissue and Organ Culture, 36: 1-7.

DOMÍNGUEZ, A; CERVERA, M; PÉREZ, R. M; ROMERO, J; FAGOAGA, C and CUBERO, J (2004). Characterisation of regenerants obtained under selective conditions after Agrobacterium-mediated transformation of citrus explants reveals production of silenced and chimeric plants at unexpected high frequencies. Mol Breeding, 14(2): 171-183.

EEUWANS, C J (1976). Mineral requirements for growth and callus initiation of tissue explants excised from mature coconut palms (Cocos nucifera) cultured in vitro. Physiol. Plant, 36: 23-28.

FANI, M O; VERSIANI, A F; DIAS, A C F; XISTO, M F; OTONI, W C; DE OLIVEIRA, L L; DA SILVA, C C; DA SILVA, E M and DE PAULA, S O (2012). Analysis of the inhibitory concentration of ammonium glufosinate in cotyledons explants of tomato plants (Solanum lycopersicon). Biotechnology, 11(3): 184-188.

FROMM, M E; MORRISH, F; ARMSTRONG, C; WILLIAMS, R; THOMAS, J and KLEIN, T M (1990). Inheritance and expression of chimeric genes in the progeny of transgenic maize plants. Bio/Technology, 8: 833-839.

IJAZ, S; ANJUM, N; RANA, I A and KHAN, I A (2012). Optimization of minimal inhibitory dose of selective agent (Basta) for selection of transgenic in sugarcane. Molecular Plant Breeding, 3(5): 50-56.

IZAWATI, A M D; PARVEEZ, G K A and ISMAIL, I (2012). Optimization of 2-Deoxyglucose concentration to identify the sensitivity of oil palm embryogenic calli. J. Oil Palm Res. Vol. 24: 1296-1302.

IZAWATI, A M D; MASANI, M Y A; ISMAIL, I and PARVEEZ, G K A (2015). Evaluation on the effectiveness of 2-deoxyglucose-6-phosphate phosphatase $\left(\mathrm{DOG}^{\mathrm{R}} 1\right)$ gene as a selectable marker for oil palm (Elaeis guineensis Jacq.) embryogenic calli transformation mediated by Agrobacterium tumefaciens. Front. Plant Sci., 6: 727. DOI: 10.3389/ fpls.2015.00727.

KAMO, K and VAN ECK, J (1997). Effect of bialaphos and phosphinothricin on plant regeneration from long- and short-term callus cultures of Gladiolus. In vitro Cell. Dev. Biol, 33: 180-183.

KAMO, K; BLOWERS, A and SMITH, F (1995). Stable transformation of Gladiolus using suspension cells and callus. J. Am. Soc. Hortic. Sci, 120: 347-353. 
KITA, Y;HANAFY,M S;DEGUCHI, M;HASEGAWA, H; TERAKAWA, T; KITAMURA, K and ISHIMOTO, $M$ (2009). Generation and characterization of herbicide-resistant soybean plants expressing novel phosphinothricin $\mathrm{N}$-acetyltransferase genes. Breeding Science, 59: 245-251.

KONDO, K; TAKAHASHI, $\mathrm{M}$ and MORIKAWA, $H$ (2002). Regeneration and transformation of a roadside tree Pittosporum tobira. Plant Biotechnology, 19: 135-139.

KOPREK, T; HÄNSEH, R; NERLICH, A; MENDEL, R R and SCHULZE, J (1996). Fertile transgenic barley of different cultivars obtained by adjustment of bombardment conditions to tissue response. Plant Science, 119: 79-91.

MAJID, N A and PARVEEZ, G K A (2007). Evaluation of green fluorescence protein (GFP) as a selectable marker for oil palm transformation via transient expression. Asia Pacific J. Molecular Biology and Biotechnology, 15(1): 1-8.

MARIANA, N M; HERNAN, R L and VICTORIO, $S$ T (2002). Transgenic wheat plants resistant to herbicide BASTA obtained by microprojectile bombardment. Biocell, 26(2): 217-223.

MASANI, M Y A; NOLL, G; PARVEEZ, G K A; SAMBANTHAMURTHI, $\mathrm{R}$ and PRUEFER, D (2014). Efficient transformation of oil palm protoplasts by PEG-mediated transfection and DNA microinjection. PLoS ONE 9(5): e96831. DOI: 10.1371 / journal.pone.0096831.

MIKI, B and MCHUGH, S (2004). Selectable marker genes in transgenic plants: applications, alternatives and biosafety. J. Biotechnology, 107: 193-232.

MURASHIGE, T and SKOOG, F (1962). A revised medium for rapid growth and bioassays with tobacco tissue cultures. Physiol. Plant, 15: 473-497.

NURFAHISZA, A R; RAFIQAH, M A; MASANI, MY A; HANIN, A N; RASID, O A; PARVEEZ, G K A and ISMAIL, I (2014). Molecular analysis of transgenic oil palm to detect the presence of transgenes. J. Oil Palm Res. Vol. 26: 96-103.

OGAWA, Y; TSURUOKA, T; INOUYE, S and NIIDA, T (1973). Studies on a new antibiotic SF-1293. Sci. Rep. Meiji Seika, 13: 42-48.

ONETO, C D; GONZÁLEZ, G and LEWI, D (2010). Biolistic maize transformation: Improving and simplifying the protocol efficiency. African J. Agriculture Research, 5(25): 3561-3570.
OTANI, M; WAKITA, Y and SHIMADA, T (2003). Production of herbicide-resistant sweetpotato [Ipomoea batatas (L) Lam.] plants by Agrobacterium tumefaciens-mediated transformation. Breeding Sci., 53: $145-148$.

PARVEEZ, G K A; RASID, O A; MASANI, MY A and SAMBANTHAMURTHI, R (2015a). Biotechnology of oil palm: strategies towards manipulation of lipid content and composition. Plant Cell Reports, 34: 533543.

PARVEEZ, G K A; BAHARIAH, B; AYUB, N H; MASANI, M Y A; RASID, O A; TARMIZI, A $\mathrm{H}$ and ISHAK, Z (2015b) Production of polyhydroxybutyrate in oil palm (Elaeis guineensis Jacq.) mediated by microprojectile bombardment of PHB biosynthesis genes into embryogenic calli. Front. Plant Sci., 6: 598. DOI: 10.3389/fpls.2015.00598.

PARVEEZ, G K A and MAJID, N A (2008). Factors affecting green fluorescence protein (GFP) gene expression in oil palm after microprojectile bombardment mediated transformation. J. Oil Palm Res. Vol. 20: 495-507.

PARVEEZ, G K A; MAJID, N A; ALIZAH, Z and OMAR, A R (2007). Determination of minimal inhibitory concentration of selection agents for selecting transformed immature embryos of oil palm. Asia Pacific J. Molecular Biology E Biotechnology, 15(3): 133-146.

PARVEEZ, G K A; RASID, O; ZAINAL, A; MASRI M M; MAJID, N A; FADILLAH, H H, YUNUS, A M M and CHEAH S C (2000). Transgenic oil palm: production and projection. Biochemistry Society Transactions, 28 (6): 969-972.

PARVEEZ, G K A; CHOWDHURY, M K U and SALEH, N M (1996). Determination of minimal inhibitory concentration of selection agents for oil palm (Elaeis guineensis Jacq.) transformation. Asia Pacific J. Molecular Biology \& Biotechnology, 4: 219-228.

SHIN, J S; KIM, K M; LEE, D J; LEE, S B; BURGOS, N R and KUK, Y I (2011). Resistance levels and fitness of glufosinate-resistant transgenic sweet-potato in field experiments. Fields Crops Research, 121: 324-332.

SUNDAR, I K and SAKTHIVEL, N (2008). Advances in selectable marker genes for plant transformation. J. Plant Physiology, 165: 1698-1716.

TACHIBANA, K; WATANABE, T; SEKIZAWA, Y and TAKEMATSU, T (1986). Action mechanism of bialaphos. J. Pest. Sci, 11: 27-31.

WEEKS, J T; ANDERSON, O D and BLECHL, A E (1993). Rapid production of multiple independent 
lines of fertile transgenic wheat (Triticum aestivum L). Plant Physiology, 102: 1077-1084.

YAN, J; KANDIANIS, CB; HARJES, C E; BAI, L; KIM, E H; YANG, X; SKINNER, D J; FU, Z; MITCHELL, S; LI, Q; FERNANDEZ, M G; ZAHARIEVA, M; BABU, R; FU, Y; PALACIOS, N; LI, J; DELLAPENNA, D; BRUTNELL, T; BUCKLER, E S; WARBURTON, M L and ROCHEFORD, T (2010). Rare genetic variation at Zea mays crtRB1 increases $\beta$-carotene in maize grain. Nature Genetics, 42(4): 322-327.

ZANG, N; ZHAI, H; GAO, S; CHEN, W; HE, S and LIU, Q (2009). Efficient production of transgenic plants using the bar gene for herbicide resistance in sweet potato. Scientia Horticulturae, 122(4): 649-653. 